\title{
HUBUNGAN PENGETAHUAN IBU DENGAN PELAKSANAAN IMUNISASI DASAR PADA BAYI DI DESA KARANG SARI HUTA 3 KECAMATAN GUNUNG MALIGAS KABUPATEN SIMALUNGUN
}

\author{
Maimunah*) \\ Surel: mumunrieto@gmail.com
}

\begin{abstract}
The objective of the research was to find out the correlation between mothers' knowledge and the implementation of basic immunization at Karang Sari Huta 3 Village, Gunung Maligas Subdistrict, Simalungn District. The research was quantitative correlation design. The population was al mothers who had babies at Karang Sari Huta 3, and the samples were 53 10-12 month-old babies. The data were gathered by distributing questionnaires and analyzed by using Spearman Rank (Rho) correlation test. The result of the research showed that the result of Spearman Rank (Rho) correlation test was 0.576 at the significance level of $1 \%$ and $p$-value $<\alpha(0.000<0.01)$ so that $H_{o}$ was rejected and $H_{a}$ was accepted which indicated that there was positive correlation between mothers' knowledge and the implementation of basic immunization in babies at Karang Sari Huta 3 Village, Gunung Maligas Subdistrict, Simalungun District. It is recommended that health care providers at this village improve health service by using the procedure and schedules about giving basic immunization to babies.
\end{abstract}

Kata Kunci: Pengetahuan, Pelaksanaan Imunisasi Dasar

\section{PENDAHULUAN}

ejalan dengan perkembangan

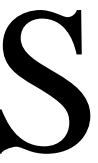
teknologi informasi global, informasi yang diperoleh masyarakat bersifat positif dan negatif terhadap imunisasi. Informasi yang negatif cenderung merubah persepsi baik masyarakat terhadap imunisasi, dimana masyarakat berpesepsi bahwa imunisasi dapat memberikan efek yang buruk pada anak. Tidak jarang dijumpai orangtua yang ragu atau bahkan menolak imunisasi dengan berbagai alasan ketakutan atau penolakan imunisasi disebabkan oleh pandangan religi bahwa vaksin tersebut haram karena mengandung unsur babi, Sebagian masyarakat berpersepsi bahwa imunisasi anak akan membuat anak terpapar dengan virus. Pandangan masyarakat terhadap vaksin pada umumnya menganggap vaksin memperoleh bibit penyakit yang dapat menimbulkan masalah kesehatan yang berbahaya,bahkan dapat menyebabkan kematian. Berhubungan dengan keamanan dan pandangan bahwa penyakit yang dapat dicegah oleh vaksinasi tidak menimbulkan masalah kesehatan yang berbahaya (Hartono, 2011).

Menurut World Health Organization (WHO) memperkirakan di seluruh dunia setiap tahunya 3 juta

*) Maimunah R. SS., M.Kes: Dosen Tetap STIKes Flora Medan 
anak meninggal akibat peenyakit yang dapat dicegah dengan imunisasi.Tak kurang dari 30 juta anak masih terhadang dari akses mendapatkan imunisasi dasar, antara lain anak-anak yang berada di negara sub-sahara Afrika, Amerika Latin danAsia, termasuk Indonesia (Musyrida, 2013). Indonesia menjadi salah satu Negara Prioritas yang diidentifikasi oleh WHO dan UNICEF untuk melaksanakan akselerasi dalam pencapaian target $100 \%$ Universal Child Immunization (UCI) Desa/Kelurahan. Gerakan Akselerasi Imunisasi Nasional (Gain) Universal Child Immunization (UCI), 2010 adalah salah satu keadaan tercapainya imunisasi dasar secara lengkap pada semua bayi (Anak dibawah umur 1 tahun) dan berdasarkan Rencana Program Jangka Menengah Nasional (RPJMN) pemerintah berkomitmen untuk mencapai target $100 \%$ desa mencapai UCI pada tahun 2014.

Cakupan imunisasi tahun 2009 untuk propinsi Sumatera Utara dengan jumlah bayi 8.224 .220 imunisasi lengkap 70\%, Imunisasi tidak lengkap $20 \%$, Tidak imunisasi sama sekali $10 \%$ (Propil Kesehatan Sumatera Utara,2010).

Imunisasi dasar sangat penting diberikan sewaktu bayi (usia 9-12 bulan) untuk memberikan kekebalan dari penyakit-penyakit yang dapat dicegah dengan imunisasi (PD3I). Tanpa imunisasi anak-anak mudah terserang berbagai penyakit, kecacatan dan kematian. Imunisasi merupakan benteng utama untuk menurunkan angka kesakitan kecacatan, dan kematian akibat beberapa penyakit, seperti tuberkulosis (Tb), difteri, pertusis (batuk rejan/batuk 100 hari), hepatitis $B$, polio, dan campak. Idealnya bayi harus mendapat imunisasi dasar lengkap yang terdiri dari BCG satu kali, DPT tiga kali, Polio empat kali, HB tiga kali, dan Campak satu kali (Anik, 2010).

Menurut Notoatmodjo (2011), pengetahuan adalah hasil 'tahu', dan ini terjadi setelah orang melakukan pengindraan terhadap suatu objek tertentu. Pengindraan terjadi melalui pancaindera manusia, yakni: indra penglihatan, pendengaran, penciuman, rasa dan raba. Sebagian besar pengetahuan manusia diperoleh melalui mata dan telinga. Pengetahuan atau kognitif merupakan domain yang sangat penting untuk terbentuknya tindakan seseorang. Karena dari pengalaman dan penelitian ternyata perilaku yang didasarkan pengetahuan akan lebih langgeng daripada perilaku yang tidak didasari oleh pengetahuan.

Hasil penelitian Syamsuddin (2007) menunjukkan bahwa respon ibu yang memiliki balita terhadap program imunisasi masih relative rendah, hal ini disebabkan karena masih ada kepercayaan masyarakat yang melarang bayi keluar rumah sebelum berusia 1 bulan, ibu enggan 
mengimunisasi bayinya karena takut resiko sakit pada anak, jarak rumah dengan tempat pelayanan imunisasi yang jauh dan keterbatasan penghasilan keluarga.

\section{MANFAAT}

Adapun manfaat dari penelitian ini adalah :

1. Hasil penelitian dapat dijadikan masukan bagi pengembangan ilmu pengetahuan tentang hubungan pengetahuan ibu dengan pelaksanaan imunisasi dasar.

2. Hasil penelitian ini dapat digunakan sebagai bahan usulan dan pertimbangan untuk meningkatkan mutu pelayanan kesehatan dikhususkan bagi pengguna posyandu.

3. Penelitian ini diharapkan dapat dijadikan bahan informasi dan pengembangan bagi penelitian sejenis yang berkelanjutan tentang hubungan pengetahuan ibu tentang imunisasi dasar pada anak.

\section{METODE PENELITIAN}

Jenis penelitian ini menggunakan kuantitatif. Desain yang digunakan dalam penilitian ini adalah korelasi yaitu suatu penelitian untuk mengetahui hubungan antara variabel satu dengan variabel lain (Notoatmodjo 2010). Peneliti ingin mengetahui hubungan pengetahuan ibu tentang imunisasi dasar dengan pelaksanaan imunisasi dasar pada Bayi di Desa Karang sari huta 3 Kecamatan Gunung Maligas Kabupaten Simalungun.

$$
\text { Pengambilan sampel }
$$

dilakukan dengan bagian dari jumlah dan karakteristik yang dimiliki oleh populasi tersebut. Bila populasi besar dan peneliti tidak mungkin mempelajari semua yang ada pada populasi (Sugiyono 2013). Sampel pada penelitian ini adalah bayi yang berumur 10 - 12 bulan. Berdasarkan survey bayi yang berumur 10-12 bulan sekitar 53 bayi, maka jumlah sampel adalah 53 bayi.

Analisa data yang digunakan dalam penelitian ini adalah (1) Analisa Univariat (2) Analisis Bivariat dengan menggunakan uji Tekhnik analisa teknik korelasi Spearman Rank (Rho).

\section{HASIL DAN PEMBAHASAN Analisi Univariat} Identitas Responden meliputi usia ibu, usia anak, pendidikan terakhir, pekerjaan, pengetahuan ibu dan pelaksanaan imunisasi dasar pada bayidiuraikan sebagai berikut :

Tabel 1 Distribusi Responden Menurut Karakteristik.

\begin{tabular}{|c|l|c|c|}
\hline No & Karakteristik & n & \% \\
\hline 1 & Umur Ibu & & \\
\hline & $20-25$ & 11 & 20 \\
\hline & $26-30$ & 28 & 52 \\
\hline & $31-35$ & 14 & 26 \\
\hline 2 & Usia Anak & & \\
\hline & 10 bulan & 20 & 37 \\
\hline & 11 bulan & 17 & 32 \\
\hline
\end{tabular}




\begin{tabular}{|c|l|c|c|}
\hline & 12 bulan & 16 & 30 \\
\hline 3 & Pendidikan & & \\
\hline & SD & 4 & 7.5 \\
\hline & SMP & 11 & 20.8 \\
\hline & SMA & 36 & 67.9 \\
\hline 4 & Diploma & 2 & 3.8 \\
\hline & $\begin{array}{l}\text { Ibu Rumah } \\
\text { Tangga }\end{array}$ & 24 & 45,3 \\
\hline & Pegawai Swasta & 7 & 13,2 \\
\hline
\end{tabular}

Berdasarkan tabel di atas dapat diketahui bahwa didapatkan mayoritas responden berada pada usia 26-30 tahun sebanyak 28 orang $(52,8 \%)$, manyoritas responden pada usia anak 10 bulan sebanyak 20 orang $(37.7 \%)$, manyoritas responden pada tingkat pendidikan SMA sebanyak 36 orang $(67.9 \%)$,

\begin{tabular}{|c|l|c|c|}
\hline & Wiraswasta & 16 & 30,2 \\
\hline & Petani & 6 & 11,3 \\
\hline 5 & Pengetahuan Ibu & & \\
\hline & Baik & 12 & 22,7 \\
\hline & Cukup & 38 & 71,7 \\
\hline 6 & Kurang & 3 & 5,7 \\
\hline & Pelaksanaan & & \\
\hline & Lmunisasi Dasar & & \\
\hline & Tidak Lengkap & 28 & 52,8 \\
\hline
\end{tabular}

manyoritas responden pada tingkat pekerjaan ibu rumah tangga sebanyak 24 orang (45.3\%), menyoritas pengetahuan ibu cukup sebanyak 38 orang $(71,7 \%)$, dan manyoritas pelaksanaan imunisasi dasar tidak lengkap sebanyak 28 orang (52.8\%).

\section{Analisa Bivariat Correlations}

Tabel 2 Hasil Analisis Korelasi Spearman Rho

\begin{tabular}{|ll|r|r|}
\hline & & $\begin{array}{c}\text { Pengetahuan } \\
\text { Ibu }\end{array}$ & \multicolumn{1}{c|}{$\begin{array}{c}\text { Pelaksanaan } \\
\text { Imunisasi } \\
\text { Dasar }\end{array}$} \\
\hline Spearman's rho Pengetahuan & $\begin{array}{l}\text { Correlation } \\
\text { Coefficient } \\
\text { Ibu }\end{array}$ & 1.000 & $.576^{* *}$ \\
& $\begin{array}{l}\text { Sig. (2-tailed) } \\
\mathrm{N}\end{array}$ &. & .000 \\
& $\begin{array}{rlr}\text { Correlation } \\
\text { Pelaksanaan }\end{array}$ & $.576^{* *}$ & 1.000 \\
Imunisasi & Coefficient & .000 & \\
Dasar & Sig. (2-tailed) & 53 & 53 \\
\hline
\end{tabular}

**. Correlation is significant at the 0.01 level (2tailed). 
1. Tabulasi Silang Hubungan Pengetahuan Ibu Dengan Pelaksanaan imunisasi dasar pada bayi di Desa Karang Sari Huta 3 Kecamatan Gunung Maligas Kabupaten Simalungun

Berdasarkan hasil uji analisis
statistik bahwa responden
yangmemiliki pengetahuan tentang
imunisasi dasar dengan kategori
cukup sebanyak 38 responden
$(71,7 \%)$, sebagian besarpelaksanaan
imunisasi dasar tidak lengkap yaitu
sebanyak 24 responden $(45,3 \%)$, dan
pelaksanaan imunisasi lengkap
sebanyak 14 responden $(26,4 \%)$.

Responden yang memiliki pengetahuan tentang imunisasi dasar dengan kategori baik sebanyak 12 responden $(22,6 \%), \quad$ sebagian besarpelaksanaan imunisasi dasar pada bayi lengkap sebanyak 11 responden $(20,8 \%)$, dan responden dengan pelaksanaan imunisasi dasar pada bayi tidak lengkap sebanyak 1 responden $(1,9 \%)$.

Responden yang memiliki pengetahuan tentang imunisasi dasar dengan kategori kurang sebanyak 3 responden $\quad(5,7 \%), \quad$ seluruhnya melakukan pelaksanaan imunisasi dasar pada bayi dengan tidak lengkap sebanyak 3 responden $(5,7 \%)$.

\section{SIMPULAN}

Dari hasil penelitian ini didapatkan bahwa responden yang memiliki pengetahuan tentang imunisasi dasar dengan kategori cukup sebagian besar proses pelaksanaan imunisasi dasar tidak lengkap yaitu sebanyak 24 responden, responden yang memiliki pengetahuan tentang imunisasi dasar dengan kategori baik sebagian pelaksanaan imunisasi dasar pada bayi lengkap sebanyak 11 responden. Sedangkan responden yang memiliki pengetahuan tentang imunisasi dasar sebagian besar pelaksanaan imunisasi dasar pada bayi dengan tidak lengkap sebanyak 3 responden.

Dimana nilai koefisien korelasi yang didapat antara pengetahuan ibu dengan pelaksanaan imunisasi dasar pada bayi di Desa Karang Sari Huta 3 Kecamatan Gunung Maligas Kabupaten Simalungun adalah sebesar 0,576 dengan taraf signifikan $1 \%$ yaitu $\mathrm{p}$ Value $<\alpha \quad(0,000<0,01)$, maka $\mathrm{H}_{\mathrm{o}}$ ditolak $\mathrm{H}_{\mathrm{a}}$ diterima. Artinya terdapat hubungan positif antara pengetahuan ibu dengan pelaksanaan imunisasi dasar pada bayi di Desa Karang Sari Huta 3 Kecamatan Gunung Maligas Kabupaten Simalungun.

Adapun saran dalam penelitian ini ialah :

1. Bagi Masyarakat

Bagi ibu-ibu yang mempunyai pengetahuan yang cukup tentang pemberian imunisasi dasar pada bayi, diharuskan untuk mendapatkan informasi mengenai imunisasi dasar 
pada bayi dan membawa bayinya untuk imunisasi.

2. Bagi Institusi Pendidikan

Diharapkan kepadaInstitusi Pendidikan untuk memberikan pendidikan tentang pemberian imunisasi dasar yang baik pada bayi serta melakukan praktik penyuluhan ke posyandu-posyandu yang ada di desa-desa sehingga mahasiswa mengerti tentang cara pemberian imunisasi dasar dan memberikan informasi yang baik tentang manfaat imunisasi dasar yang baik bagi bayi.

3. Bagi Tenaga Kesehatan

Diharuskan bagi tenaga kesehatan yang ada di Desa Karang Sari Huta 3 Kecamatan Gunung Maligas Kabupaten Simalungun harus lebih meningkatkanlagi pelayanan kesehatan dengan prosedur dan jadwal-jadwal yang telah ditentukan tentangpemberian imunisasi dasar pada bayi.

\section{Bagi Peneliti Lain}

Hasil penelitian ini dapat dijadikan referensi untuk melakukan penelitian sejenis dengan sampel yang lebih banyak. Penelitian ini perlu dilanjutkan oleh peneliti selanjutnya untuk mengetahui faktor-faktoryang mempengaruhi pengetahuan, sikap dari tindakan pada ibu dalam pemberian imunisasidasar pada bayi.

\section{DAFTAR PUSTAKA}

Departemen Kesehatan RI 2000.Mengenal Imunisasi dan PD3I. Jakarta

Dinas Kesehatan Sumatera Utara (2010). Profil Kesehatan Sumatera Utara tahun 2010. (online).

http://www.Depkes.go.id

Dinas kesehatan Simalungun profil

Kesehatan Puskesmas

Gunung Maligas tahun 2010

KIA, 2011. Buku Kesehatan Ibu dan Anak. Diunduh pada tanggal 17

februari darihttp://www.depkes.go.id/ downloads/jica/kia.pdf

Maryuani. (2010). Ilmu Kesehatan Anak Dalam Kebidanan. Jakarta : TIM

Maryanti.Dwi.dkk, 2011. Buku Ajar Neonatus, Bayi Balita. Cilacap : trans info media Jakarta

Menkes RI 2010. Pedoman Gerakan Akselerasi Imunisasi Nasional Universal Child Imunization 2010-2014 (Gain Uci 2010-2014)

Notoatmodjo, S. 2010. Ilmu Perilaku Kesehatan. Jakarta : Rineka Cipta

Rafika, 2013. Gambaran Pengetahuan Ibu yang Mempunyai Bayi Tentang Imunisasi dasar Pada Bayi di Lingkungan II Keluharan Tanjung Gusta Medan 2013. 
Diunduh dari :

http://balitbang.pemkomedan

.go.id/tinymcpuk/gambar/file/

$\underline{\text { Rafika.pdf }}$

Soejatmiko, 2009. Imunisasi Penting

Untuk Mencegah Penyakit

Berbahaya Tahun 2009.

(online).

http://wwwIDAI.go.id

Sugiyono, 2013. Metode Penelitian

Pendidikan. Jakarta :

Alfabeta. 